\title{
Factors associated with the survival and marginal bone loss of dental implants: a 5-year retrospective study
}

\author{
Eul-Rak Song ${ }^{+}$, Jae-Kwan Lee+, Heung-Sik Um, Se-Hwan Park, Beom-Seok Chang* \\ Department of Periodontology, Research Institute for Oral Sciences, College of Dentistry, Gangneung-Wonju National University, \\ Gangneung, Republic of Korea
}

Purpose: The purpose of this study was to compare the long-term survival rate and peri-implant marginal bone loss related to multiple risk factors including the clinician's experience. Materials and Methods: Four hundred twenty implants in 146 patients, who had involved a supportive periodontal therapy program every 3 to 6 months and had follow up data for at least 5 years, were selected as the study group. Peri-implant marginal bone loss, data of demographic, implant and surgical characteristics were collected from peri-apical radiographs and chart review. Implant survival was regarded as the remaining with radiographic marginal bone level in excess of $50 \%$ of the fixture length for any reason. Results: The cumulative survival rate after 5 years of loading was 94.9\%. In binary logistic regression analysis, smoking status $(P=0.033)$ and presence of spontaneous cover screw exposure $(P<$ 0.001 ) were significantly related to 5 -year survival of implants. In stepwise multiple regression analysis, smoking status $(P<0.001)$, type of abutment connection $(P<0.001)$ and implant surface $(P=0.033)$ were significantly related to peri-implant marginal bone level. And the year of resident was not statistically related to 5 -year implant survival in simple logistic regression analysis $(P=0.171)$. Conclusion: Smoking status, spontaneous cover screw exposure, type of abutment connection and implant surface might influence the implant success. There was no significant correlation between the year of resident and implant failure. (J Dent Rehabil Appl Sci 2016;32(4):280-92)

Key words: dental implant; alveolar bone loss; cumulative survival rate; risk factor

\section{Introduction}

Dental implants are a predictable treatment option for intra-oral prosthetic reconstruction. The survival rates of osseointegrated dental implants are 89.2 $95.5 \%$, as reported in systematic review over the last 5 years. ${ }^{1}$ The stability of bone level around dental implants is one of the important factors in long-term implant success. However, certain biological and technical complications may lead to implant failure and peri-implant bone loss. ${ }^{2,3}$ Previous periodontal

*Correspondence to: Beom-Seok Chang

Professor, Department of Periodontology, Gangneung-Wonju National University

College of Dentistry, 7 Jukheon-gil, Gangneung, 25457, Republic of Korea

Tel: +82-33-640-3188, Fax: +82-33-640-3113, E-mail: dentist@gwnu.ac.kr

Received: September 9, 2016/Last Revision: December 5, 2016/Accepted:

December 13, 2016

+ Eul-Rak Song and Jae-Kwan Lee contributed equally to this study. disease, poor plaque control, smoking, and diabetes are included as risk factors that may lead to periimplant mucositis and peri-implantitis, as reported by the American Academy of Periodontology. ${ }^{4}$ In patients with a history of periodontitis, however, preventive maintenance programs can reduce the incidence of peri-implantitis. ${ }^{5,6}$ In four systematic reviews, smoking was described as a negative factor in implant outcome and affects survival rate and marginal bone loss. ${ }^{7-10}$ However, other studies found no significant relationship between smoking and im-

Copyright (C 2016 The Korean Academy of Stomatognathic Function and Occlusion. (c) It is identical to Creative Commons Non-Commercial License. 
plant outcome. ${ }^{11,12}$ Uncontrolled diabetes has been described as affecting implant survival. Hyperglycemia may compromise the healing of soft tissues, resulting in implant failure. ${ }^{13}$ However, in a systematic review, diabetes was not proven to be a risk factor for the rate of implant survival. ${ }^{9,14}$ Other risk factors may influence implant survival. Whether the implant is exposed or submerged in healing may impact the outcome $^{15}$ Spontaneous implant exposure is a risk factor when submerged type healing is planned. Furthermore, spontaneous early exposure of submerged implants may be associated with abnormal healing. ${ }^{16}$ All of these risk factors must be considered in the prognosis of implant success.

The experience of the clinician is another controversial factor in the prognosis of implant success and survival rate. ${ }^{17-22}$ However, to the best of our knowledge, no long-term retrospective study considering the clinician's experience as a risk factor of implant survival and peri-implant marginal bone loss (MBL) has been conducted. Clarification of the impact of the clinician's experience on long-term implant survival is required for informed consent and treatment planning.

For the diagnosis of long-term functional and esthetic success of implants, osseointegration and the peri-implant marginal bone levels were evaluated radiographically. ${ }^{23,24}$ Correct interpretation of the radiographic assessment of marginal bone levels is essential for long-term follow-up. ${ }^{24}$ Panoramic radiographs show a specific distortion of the shape and size of the dental arch, resulting in limited resolution. ${ }^{25}$ Periapical radiographs have been used widely to evaluate interproximal bone change during longterm implant maintenance sessions. ${ }^{24}$ Furthermore, the introduction of digital radiography allows a more precise assessment of radiographs from $0.1-0.3 \mathrm{~mm}$ to $<0.1 \mathrm{~mm}$ on a computer. ${ }^{24}$ The bone loss around the implant after implant placement is expected to be $0.5-2 \mathrm{~mm}$ in the first year, and a bone loss of $0-0.2$ $\mathrm{mm}$ per year is expected thereafter. ${ }^{26-28}$

Therefore, the purpose of this retrospective study was to compare the long-term survival rate and MBL related to multiple risk factors including the clinician' s experience.

\section{Materials and Methods}

\section{Data collection}

In this retrospective study, all implants were placed by periodontology residents at the Department of Periodontics of the Gangneung-Wonju National University Dental Hospital from January 2002 to March 2009. This study was approved by Institutional Review Boards at the Gangneung-Wonju National University Dental Hospital (IRB 2014-7). All patients included in the retrospective review were treated with the 2-staged surgical procedure. During the period, 2890 implants in 1154 patients were installed. Of these patients, 328 patients, who were treated with 852 implants, were followed. Four hundred eighty nine implants installed by residents in the Department of Periodontics in 196 patients were recruited. Sixty-nine implants in 50 patients were excluded because of insufficient follow-up data or the lack of digital periapical radiographs of at least 5 years. Thus, 420 implants in 146 patients were included in this study (Fig. 1). The prosthetic rehabilitation was completed at the Department of Prosthodontics of the Gangneung-Wonju National University Dental Hospital.

The following patient data was collected from the retrospective chart review (Table 1):

- Gender

- Age at implant placement (three groups: $<45$ years, 45 - 54 years, and $\geq 55$ years)

- History of type 2 diabetes mellitus; smoking status (a smoker was classified as at least 1 cigarette per day at the time of implant placement)

- Surface of implant (three groups: blasted, anodized, and blasted and acid etched surface); implant product used according to the abutment connection type [two groups: internal type (1. Implantium, Dentium, Seoul, Korea; 2. GS II, Osstem, Seoul, Korea; 3. Osseospeed, Astra Tech AB, Mölndal, Sweden; 4. Replace, Nobel Biocare AB, Gothenburg, Sweden; and external type (5. Biomet 3 i osseotite, Implant Innovations, Palm Beach Gardens, FL, USA; 6. Brånemark Mk III, Nobel Biocare AB; 7. Neoplant, Neobiotech, 


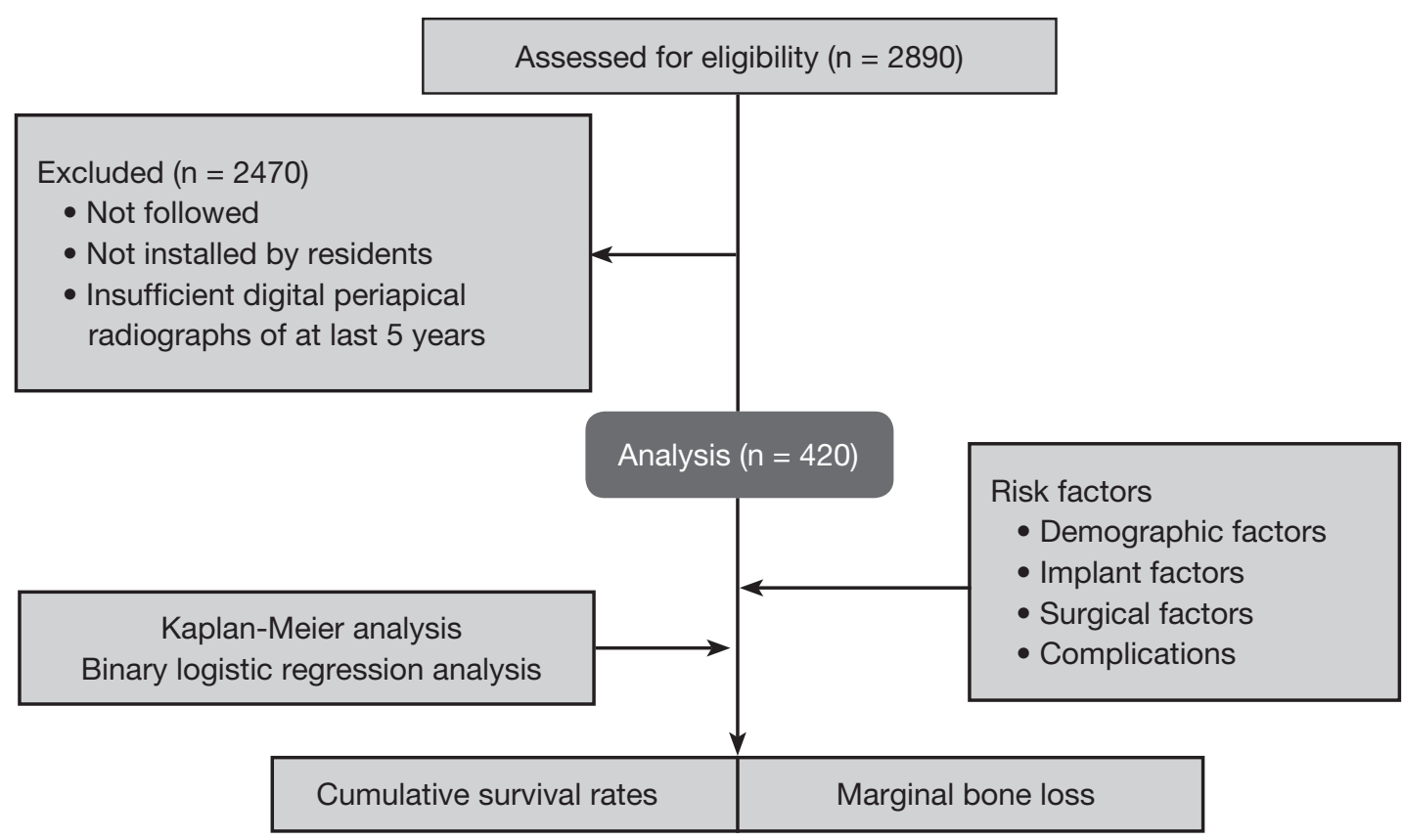

Fig. 1. Flow diagram of the study.

Table 1. Data collection

\begin{tabular}{clll}
\hline Demographic factors & \multicolumn{1}{c}{ Implant factors } & \multicolumn{1}{c}{ Surgical factors } & \multicolumn{1}{c}{ Complications } \\
\hline Gender & Abutment connection & Resident experience & Spontaneous cover screw exposure \\
Age & Surface of implant & Bone augmentation surgery & Prosthetic complications \\
Type 2 DM & Diameter & Peri-implant plastic surgery & \\
Smoking & Implant location & & \\
\hline
\end{tabular}

DM, diabetes mellitus.

Seoul, Korea; 8. US II, Osstem)]

- Implant diameter (three groups: $<4$ mm, $4-4.5$ $\mathrm{mm}$, and $\geq 5 \mathrm{~mm}$ )

- Location of implant within the dental arch (four groups: maxillary anterior, maxillary posterior, mandibular anterior, and mandibular posterior regions)

- Year of the resident at the time of implant placement

- Spontaneous early exposure of cover screw (CS) during the healing phase

- Prosthetic complications (fracture of abutment, abutment screw and implant prosthesis; loosening of abutment screw and implant prosthesis; and chipping of veneering ceramic)

- Bone augmentation procedures [procedures such as guided bone regeneration (GBR), sinus elevation with crestal approach (Crestal), and sinus elevation with lateral approach (Lateral). If GBR and one of the sinus elevation procedures were applied to the same area simultaneously, the implant was classified as sinus elevation group]

- Peri-implant plastic surgeries (procedures such as apically repositioned flap and gingival graft)

- Dates of implant placement, prosthesis placement, implant removal, and the last follow-up visit. 


\section{Peri-implant marginal bone level evaluation}

Intraoral periapical radiographs were taken after placement of the implant, connection of the temporary healing abutment, and during the annual followup. Digital periapical radiographs were taken using the intraoral X-ray system (CS 2200, Carestream, Rochester, USA) with intraoral digital sensor (1. SuniRay, Suni, Califonia, USA or 2. RVG 6100, Carestream). The parallel long-cone technique with a Rinn system film holder (XCP Instruments, Dentsply Rinn, York, USA) was used with the implant parallel to the digital sensor and X-ray tube. This method resulted in an accurate visualization of the implant threads. Peri-implant bone loss was assessed by measuring the linear bone change from the abutment-fixture junction to the first bone-to-implant contact at the mesial and distal site of each implant. This measurement was performed using PC-based digital soft- ware (Infinitt Pacs, Infinitt healthcare, Seoul, Korea), which allows magnification and precise assessment at $0.01 \mathrm{~mm}$. After comparing the mesial and distal bone loss values, the higher of the two was considered the peri-implant bone loss for the implant (Fig. 2). Peri-implant bone loss was calculated by multiplying the change in linear bone value with actual fixture length/radiographic fixture length. All radiographic measurements were recorded by one examiner.

Implant failure was defined as radiographic bone loss in more than $50 \%$ of the fixture length or the removal of an implant for any reason. ${ }^{29}$ The survival period was defined as the time interval from implant placement to implant removal, achieving radiographic bone loss of over $50 \%$ of the fixture length, or the time of the last follow-up visit. Implant failure timing can be divided into early and late failure according to the time of loading. ${ }^{28}$

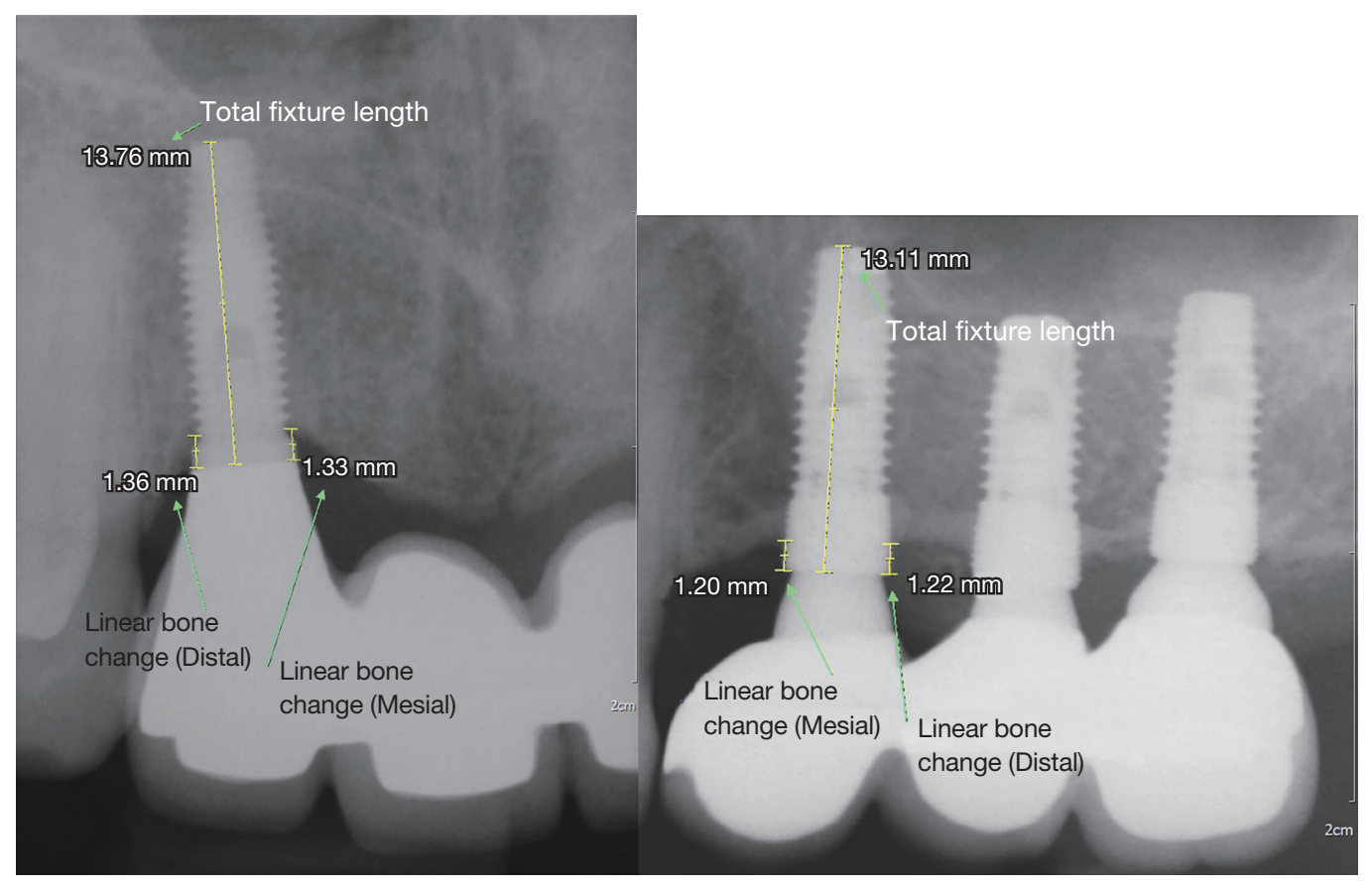

Fig. 2. Radiographs of the measurements of linear bone change and total fixture length. MBL was assessed by measuring the linear bone change from the abutment-fixture junction to the first bone-to-implant contact at the mesial and distal site of each implant. After comparing the mesial and distal bone loss values, the higher of the two was considered the MBL. 


\section{Statistical analyses}

The cumulative survival rates of implants of 5 years loading (CSR5s) were calculated by the life table method at annual intervals and Kaplan-Meier analysis. Implant outcomes can be divided into two types: implant survival and radiographic marginal bone levels. To discriminate potential risk factors associated with implant survival, binary logistic regression analysis was performed. First, simple logistic regression analysis was performed between the 5-year survival rate of the implants and each independent variable of interest separately. The independent variables that associated significantly with implant survival of 5-years in simple logistic regression analysis $(P<0.05)$ were included in multiple regression analysis. Multivariate odds ratios, confidence intervals, and $P$ values resulting from multiple logistic regression analysis were described. To identify the potential risk factors needed to predict MBL, stepwise multiple regression analysis was performed. The same independent variables as those in the analysis of implant survival were included. In stepwise multiple regression analysis, unstandardized regression coefficients, standard errors, partial R-squares, and $P$ values were described. All the independent variables with a $P<$
0.05 were considered statistically significant. All statistical procedures were performed using statistical software (SPSS ST1, IBM Inc., Chicago, USA).

\section{Results}

The screnning process is presented in Fig. 1. During the period from January 2002 to March 2009, 2890 implants in 1154 patients were installed. Only the patients involved in follow-up appointments every 3 to 6 months for at least 5 years were included. Thus, 420 implants in 146 patients were included in this study.

\section{Demographic characteristics}

Of the 420 implants included in the study, all of the patients had follow-up data of at least 5 years from implant placement. The mean follow-up period from implant placement was 8.0 years [standard deviation (SD), 1.84; range, 5.0 to 12.3 years]. Table 2 lists the patients included in the independent variable group in the simple logistic regression analysis. In simple logistic regression analysis, patient gender $(P$ $=0.023)$ and smoking status $(P=0.002)$ were associated significantly with the 5-year survival of implants.

Table 2. Distribution of implants according to demographic characteristics

\begin{tabular}{|c|c|c|c|c|}
\hline & $\begin{array}{c}\text { Survived implants } \\
\mathrm{N}(\%)\end{array}$ & $\begin{array}{l}\text { Failed implants } \\
\text { N }(\%)\end{array}$ & $\begin{array}{l}\text { Total implants } \\
\text { N }(\%)\end{array}$ & $P$ value \\
\hline Gender & & & & $0.023^{*}$ \\
\hline Female & $147(35.0)$ & $2(0.5)$ & $149(35.5)$ & \\
\hline Male & $252(60.0)$ & $19(4.5)$ & $271(64.5)$ & \\
\hline Age (years) & & & & 0.833 \\
\hline$<45$ & $108(25.7)$ & $5(1.2)$ & $113(26.9)$ & \\
\hline $45-54$ & $201(47.9)$ & $12(2.9)$ & $213(50.7)$ & \\
\hline$\geq 55$ & 90 (21.4) & $4(1.0)$ & 94 (22.4) & \\
\hline Mean $(\mathrm{SD})$ & $49.3(6.72)$ & $48.9(6.30)$ & $49.3(6.69)$ & \\
\hline Type 2 DM & & & & 0.550 \\
\hline No & $364(86.9)$ & $20(4.8)$ & 384 (91.7) & \\
\hline Yes & $34(8.1)$ & $1(0.2)$ & $35(8.3)$ & \\
\hline Smoking & & & & $0.002 * *$ \\
\hline No & $286(68.1)$ & $8(1.9)$ & $294(70.0)$ & \\
\hline Yes & $113(26.9)$ & $13(3.1)$ & $126(30.0)$ & \\
\hline
\end{tabular}

$\mathrm{SD}$, standard deviation; $\mathrm{DM}$, diabetes mellitus.

$* P<0.05$; ** $P<0.01$. 


\section{Implant characteristics}

In total, 420 implants were placed by 16 periodontology residents. Table 3 presents the implant characteristics according to 5-year survival. In simple logistic regression analysis, implant location $(P=0.028)$ was associated significantly with 5-year survival of implants. Survival rate of implant in posterior maxilla was significantly lower than that of implant in other location.

\section{Surgical characteristics and the presence of complications}

All implants included in this study were placed using the 2-staged surgical procedure. After installation of the implant fixture, spontaneous CS exposure was observed in 68 implants $(16.2 \%)$. Thirteen implants (3.1\%) were placed by first year residents, 226 implants $(53.8 \%)$ were placed by second year residents, and 181 implants (43.1\%) were placed by third year residents. Bone augmentation procedures were applied with 188 implants (44.8\%), and 232 implants
$(55.2 \%)$ were placed with conventional surgical techniques.

Table 4 lists the surgical characteristics and the existence of complications according to the 5 -year survival. In simple logistic regression analysis, the presence of spontaneous CS exposure $(P<0.001)$ and the application of bone augmentation procedures $(P=0.001)$ were associated significantly with 5 -year survival of implants. Resident experience was not a significantly influencing factor in 5-year implant survival.

\section{Implant survival}

During the process of healing, 10 implants $(2.4 \%)$ failed in osseointegration and were removed. Eleven implants $(2.6 \%)$ failed after 5 -years of functional loading. Of these 11 implants, $9(2.1 \%)$ were removed and $2(0.5 \%)$ were classified as failed due to radiographic marginal bone levels at less than half of the fixture length. According to the Kaplan-Meier lifetime analysis, CSR5s was $94.9 \%$, and that after 10 years of loading was $93.2 \%$ (Table 5 ).

Table 3. Distribution of implants according to implant characteristics

\begin{tabular}{|c|c|c|c|c|}
\hline & $\begin{array}{c}\text { Survived implants } \\
\text { N }(\%)\end{array}$ & $\begin{array}{c}\text { Failed implants } \\
\mathrm{N}(\%)\end{array}$ & $\begin{array}{c}\text { Total Implants } \\
\text { N }(\%)\end{array}$ & $P$ value \\
\hline Abutment connection & & & & 0.490 \\
\hline Internal & $103(24.5)$ & $4(1.0)$ & $107(25.5)$ & \\
\hline External & $296(70.5)$ & $17(4.0)$ & $313(74.5)$ & \\
\hline Surface of implant & & & & 0.611 \\
\hline Blasted & $165(39.3)$ & $11(2.6)$ & $176(41.9)$ & \\
\hline Anodized & $96(22.9)$ & $4(1.0)$ & $100(23.9)$ & \\
\hline Blasted and acid etched & $138(32.9)$ & $6(1.4)$ & $144(34.3)$ & \\
\hline Diameter $(\mathrm{mm})$ & & & & 0.596 \\
\hline$<4$ & $54(12.9)$ & $0(0.0)$ & $54(12.9)$ & \\
\hline 4 to 4.5 & $264(62.9)$ & $14(3.3)$ & $278(66.2)$ & \\
\hline$\geq 5$ & $81(19.3)$ & $7(1.7)$ & $88(21.0)$ & \\
\hline Mean (SD) & $4.21(0.23)$ & $4.46(0.12)$ & $4.22(0.46)$ & \\
\hline Implant location & & & & $0.028^{*}$ \\
\hline Mandibular anterior & $13(3.1)$ & $0(0.0)$ & $13(3.1)$ & \\
\hline Maxillary anterior & $32(7.6)$ & $0(0.0)$ & $32(7.6)$ & \\
\hline Mandibular posterior & $200(47.6)$ & $4(1.0)$ & $204(48.6)$ & \\
\hline Maxillary posterior & $154(36.7)$ & $17(4.0)$ & $181(40.7)$ & \\
\hline
\end{tabular}

SD, standard deviation.

$* P<0.05$ 
Table 4. Distribution of the implants according to surgical characteristics and the existence of complications

\begin{tabular}{|c|c|c|c|c|}
\hline & $\begin{array}{c}\text { Survived implants } \\
\mathrm{N}(\%)\end{array}$ & $\begin{array}{c}\text { Failed implants } \\
\mathrm{N}(\%)\end{array}$ & $\begin{array}{c}\text { Total implants } \\
\mathrm{N}(\%)\end{array}$ & $P$ value \\
\hline Resident experience & & & & 0.171 \\
\hline $1^{\text {st }}$ year & $12(2.9)$ & $1(0.2)$ & $13(3.1)$ & \\
\hline $2^{\text {nd }}$ year & $219(52.1)$ & $7(1.7)$ & $226(53.8)$ & \\
\hline $3^{\text {rd }}$ year & $168(40.0)$ & $13(3.1)$ & $181(43.1)$ & \\
\hline Spontaneous CS exposure & & & & $<0.001 * *$ \\
\hline Absence & $342(81.4)$ & $10(2.4)$ & $352(83.8)$ & \\
\hline Presence & 57 (13.6) & $11(2.6)$ & $68(16.2)$ & \\
\hline Prosthetic complications & & & & 0.561 \\
\hline Absence & $358(85.2)$ & $18(4.3)$ & $376(89.5)$ & \\
\hline Presence & $41(9.8)$ & $3(0.7)$ & $44(10.5)$ & \\
\hline Bone augmentation surgery & & & & $0.001 * *$ \\
\hline Conventional & $224(53.3)$ & $8(1.9)$ & $232(55.2)$ & \\
\hline GBR & $107(25.5)$ & $2(0.5)$ & $109(26.0)$ & \\
\hline $\mathrm{S} / \mathrm{E}$ (Crestal) & $30(7.1)$ & $7(1.7)$ & $37(8.8)$ & \\
\hline S/E (Lateral) & $38(9.0)$ & $4(1.0)$ & $42(10.0)$ & \\
\hline Peri-implant plastic surgery & & & & 0.417 \\
\hline Absence & $270(64.3)$ & $16(3.8)$ & $286(68.1)$ & \\
\hline Presence & $129(30.7)$ & $5(1.2)$ & $134(31.9)$ & \\
\hline
\end{tabular}

CS, cover screw; GBR, guided bone regeneration; S/E, sinus elevation.

** $P<0.01$.

Table 5. Cumulative survival rate of inserted implants

\begin{tabular}{cccc}
\hline Time (year) & $\begin{array}{c}\text { No. of Implants at beginning } \\
\text { of interval }\end{array}$ & $\begin{array}{c}\text { No. of failed Implants during } \\
\text { interval }\end{array}$ & $\begin{array}{c}\text { Cumulative survival rate } \\
(\%)\end{array}$ \\
\hline Place/Load & 410 & 10 & 97.6 \\
Load / 1 & 410 & 0 & 97.6 \\
1 to 2 & 406 & 4 & 96.7 \\
2 to 3 & 403 & 3 & 95.9 \\
3 to 4 & 402 & 1 & 95.7 \\
4 to 5 & 399 & 3 & 94.9 \\
5 to 6 & 398 & 1 & 94.6 \\
6 to 7 & 396 & 2 & 93.8 \\
7 to 8 & 395 & 1 & 93.2 \\
8 to 9 & 395 & 0 & 93.2 \\
9 to 10 & 395 & 0 & 93.2 \\
\hline
\end{tabular}

Place/Load, placement of implant to time of loading; Load/1, time of loading to 1 year.

\section{Risk factors associated with implant survival}

Based on simple logistic regression analysis, patient gender $(P=0.023)$, smoking status $(P=0.002)$, location of implant $(P=0.028)$, presence of spon- taneous CS exposure $(P<0.001)$, and application of bone augmentation procedures $(P=0.001)$ were significantly associated with the 5-year survival of implants. The independent variables were included in multiple regression analysis. 
In multiple logistic regression analysis, smoking status $\{P=0.033$; Odds ratio $(\mathrm{OR}) 3.263\}$ and the presence of spontaneous CS exposure $(P<0.001$; OR 6.523) were related significantly to the 5 -year survival of implants (Table 6).

\section{Peri-implant marginal bone level}

Periapical radiographs were taken during the follow-up period (mean 7.1; SD 1.39; range 5.0 - 10.8 years after implant placement). The overall mean interproximal bone loss was $1.71 \mathrm{~mm}(\mathrm{SD}, 1.21$; range, $0.00-8.22 \mathrm{~mm}$ ).

In order to evaluate the risk factors contributing to MBL, univariate linear regression and stepwise multiple regression analysis was performed. MBL was higher in smokers (mean, $2.07 \mathrm{~mm}$; SD, 0.12) than in non-smokers (mean, $1.56 \mathrm{~mm}$; SD, 0.68). Association of MBL with variable factors by univariate linear regression analysis was presented in Table 7. Smoking

Table 6. Multiple logistic regression analysis for risk factors associated with 5-year implant survival

\begin{tabular}{lccc}
\hline & Multivariate Odds ratio & $95 \%$ Confidence Interval & $P$ value \\
\hline Smoking & & & $0.033^{*}$ \\
$\quad$ Smoking & 3.263 & 1.097 to 9.707 & $0.033^{*}$ \\
Implant position & & & 0.530 \\
$\quad$ Mandibular posterior & 0.358 & 0.092 to 1.388 & 0.137 \\
$\quad$ Maxillary anterior & $<0.001$ & 0.000 & 0.998 \\
$\quad$ Mandibular anterior & $<0.001$ & 0.000 & 0.999 \\
Spontaneous CS exposure & & & $<0.001^{* *}$ \\
$\quad$ Presence & 6.523 & 2.411 to 17.650 & $<0.001^{* *}$ \\
Bone augmentation procedure & & & 0.206 \\
$\quad$ Guided bone regeneration & 0.493 & 0.092 to 2.645 & 0.409 \\
$\quad$ Sinus elevation (Crestal) & 2.896 & 0.766 to 10.953 & 0.117 \\
Sinus elevation (Lateral) & 1.034 & 0.228 to 4.695 & 0.965 \\
\hline
\end{tabular}

CS, cover screw.

** $P<0.01 ; * P<0.05$.

Table 7. Association of periapical bone loss of implants over 5-years with variable factors by univariate linear regression analysis

\begin{tabular}{lcc}
\hline \multicolumn{1}{c}{ Variables } & $\beta \pm \mathrm{SE}$ & $P$ value \\
\hline Smoking & $0.505 \pm 0.131$ & $<0.001^{* *}$ \\
Patient gender & $-0.051 \pm 0.126$ & 0.687 \\
Patient age & $0.009 \pm 0.009$ & 0.316 \\
Resident experience & $-0.126 \pm 0.111$ & 0.254 \\
Resident experience $(2-3)$ & $-0.256 \pm 0.124$ & $0.040^{*}$ \\
Abutment connection & $0.837 \pm 0.132$ & $<0.001^{* *}$ \\
Implant product & $0.135 \pm 0.026$ & $<0.001^{* *}$ \\
Diameter of implant & $-0.323 \pm 0.132$ & $0.015^{*}$ \\
Implant position & $-0.025 \pm 0.045$ & 0.583 \\
Cover screw exposure & $0.236 \pm 0.172$ & 0.169 \\
Prosthetic complication & $0.045 \pm 0.200$ & 0.821 \\
Bone augmentation surgery & $0.027 \pm 0.063$ & 0.663 \\
Periodontal plastic surgery & $-0.035 \pm 0.129$ & 0.787 \\
\hline
\end{tabular}

SE, standard errors.

** $P<0.01 ; * P<0.05$. 
Table 8. Association of peri-implant bone loss of implants over 5-years with variable factors by stepwise multiple regression analysis

\begin{tabular}{cccc}
\hline & $\beta \pm \mathrm{SE}$ & Partial R & $P$ value \\
\hline Smoking & $0.551 \pm 0.134$ & 0.099 & $<0.001^{* *}$ \\
Abutment connection & $0.869 \pm 0.132$ & 0.041 & $<0.001^{* *}$ \\
Surface of implant & $0.143 \pm 0.067$ & 0.011 & $0.033^{*}$ \\
\hline
\end{tabular}

status $(P<0.001)$, type of abutment connection $(P<$ $0.001)$, and implant surface $(P=0.033)$ were related significantly to peri-implant marginal bone levels (Table 8).

\section{Discussion}

Our study was designed to compare the long-term survival rate and MBL related to multiple risk factors including the clinician's experience. In the assessment of implant prognosis, only clinical and radiographic evaluations from patients with at least 5 years follow-up were used. In a consensus report from the $3^{\text {rd }}$ European Workshop on Periodontology, requirements for the design of longitudinal studies were described, and the recommended study duration for the evaluation of general implant system was established as $5-10$ years. ${ }^{30}$ Thus, our study fulfills the general recommendation that the long-term study duration for the evaluation of general implant systems should be longer than 5 years. Several other reports suggest that the mean study duration for significant analysis of survival and complication rates is at least 5 years, and studies with a mean follow-up time of less than 5 years should be excluded in systematic reviews. ${ }^{2,31}$

In the present study, CSR5s was $94.9 \%$, which is comparable to results reported in previous studies. ${ }^{1,31}$

Unlike most studies that defined the survival of the implant as the presence of the retained implant over the follow-up period, the survival of dental implant was defined in this study as the implant remaining with radiographic marginal bone levels in excess of $50 \%$ of the fixture length. In the study of Bain and Moy, ${ }^{29}$ who defined implant survival with the same criteria, the overall survival rate of implants over a 6-year period was $94.08 \%$, which is comparable to our results.

As a potential risk factor, we identified the year of residence as the clinician's experience. The year of residence was not related statistically to the 5-year implant survival in simple logistic regression analysis $(P=0.171)$. In previous studies that considered the clinician's experience as a risk factor for implant failure, a variety of criteria to determine clinician's experience were used. ${ }^{17-21}$ In the previous studies that used the same criteria for clinician's experience as in this study, there was no significant relationship between the year of residence and implant outcome. ${ }^{19-21}$ However, Zoghbi et al. ${ }^{18}$ divided clinicians into 2 groups by experience based on whether the clinicians had placed $\geq$ or $<50$ implants. They reported a statistical association with clinician's experience and implant failure. In addition, Preiskeil and Tsolka ${ }^{17}$ classified the experience of clinicians as performing implant placement for 2 years, and showed that clinician's experience had a significant influence on implant failure. From the results of these studies, the criteria used to classify the clinician's experience in this study, the year of residence, may not be suitable. Therefore, another criteria for clinician's experience, which may unify the other factors, is needed in future studies.

In this study, one of the variables that associated statistically with 5 -year implant survival $(P<0.05)$ was smoking status $(P=0.033)$. Smoking increased the incidence of implant failure $3.26 \mathrm{X}$, as demonstrated in multiple logistic regression analysis. Of 21 implants that failed, 13 were placed in patients with smoking status. Additionally, two of three patients with a history of multiple implant failure were smok- 
ers. Bain and $\mathrm{Moy}^{29}$ and Ekfeldt et al. ${ }^{32}$ assessed the factors associated with multiple implant failures in the maxilla, and described that heavy smoking $(>10$ cigarettes/day) was associated with a cluster phenomenon of implant failures.

Spontaneous CS exposure was related statistically to implant failure in the present study $(P<0.001)$. This association has been reported previously. ${ }^{33}$ Spontaneous early perforation and exposure of the CS may be associated with plaque accumulation and with trauma and infection in early phase of healing, and, thus, may be a negative factor in implant outcomes. In the present study, all of the implants were placed using a 2-stage surgical procedure. A high CS, approximately $1 \mathrm{~mm}$ in length, was positioned over the external type of implants, and a flat CS was positioned over the internal type of implants. The incidence of spontaneous CS exposure was higher in the external type of implants (17.6\%) than in internal type of implants $(12.1 \%)$. Schwartz et al. ${ }^{33}$ reported that implants with high cover screws increased the incidence of early CS exposure over implants with flat cover screws.

In this study, the mean of MBL over 5-years was $1.71 \mathrm{~mm}$ (SD, 1.21). There was a significant association between smoking status and MBL by stepwise multiple regression analysis $(P<0.001)$. In 22 prospective or retrospective studies to evaluate the association between smoking and MBL reviewed by Heitz-Mayfield et al., ${ }^{28} 18$ studies showed that smoking status has a significant association with MBL.

Abutment connection type was a significant risk factor to radiographic MBL by stepwise multiple linear regression analysis $(P=0.04)$. The marginal bone-loss of implants with an external abutment connection (mean, $1.93 \mathrm{~mm}$; SD, 1.20) was higher compared to implants with an internal abutment connection type (mean, $1.09 \mathrm{~mm}$; SD, 1.01). A few studies have analyzed MBL in relation to abutment connection type. ${ }^{34-36}$ In prospective clinical studies, Koo et $a l^{34}$ and Peñarrocha Diago et al..$^{35}$ described MBL were significantly greater for the external compared to the internal connection. However, only a small number of implants were analyzed and the duration of the study was less than a year. Vázquez Álvarez et $a^{36}{ }^{36}$ reported a significant correlation between periimplant bone loss and implant connection system in a retrospective study, but the radiographic bone loss was assessed in panoramic radiographs, which, due to low resolution, may distort the image.

The surface type of implant was related statistically to MBL by stepwise multiple linear regression analysis $(P=0.03)$. MBL with an anodized surface (mean, $1.91 \mathrm{~mm}$; SD, 1.56) was higher than that in implants with a blasted surface (mean, $1.61 \mathrm{~mm}$; SD, 0.99) or a blasted and acid etched surface (mean, $1.70 \mathrm{~mm}$; SD, 1.21). However, even within the same classification of implant surface, each implant may have specific detailed surface components. There are a limited number of studies evaluating the impact of different surface modifications on peri-implant bone loss. In a review of different implant surfaces on marginal bone levels, Abrahamsson and Berglundh ${ }^{37}$ stated that no implant system was superior in marginal bone preservation.

One limitation of the present study is that the period from implant installation to obtaining periapical radiographs was not uniform. Digital periapical radiography systems were introduced at GangneungWonju National University Dental Hospital in 2010. Thus, implants placed before 2005 only had 5 more years of radiographic follow-up. Another limitation in our radiographic analysis is that implants removed within 5 years after installation were excluded from our study. Therefore, a comprehensive analysis including MBL and failure of osseointegration is limited. In addition, the variety of implant products used in this study may increase the risk of bias in analysis. In studies that assessed the abutment connection system as a risk factor of implant outcome, one product for each abutment system was analyzed and other potential factors including surface, form, length, and diameter tended to be unified. ${ }^{34-36}$ As a retrospective study, other criteria for classifying clinician experience could not be adapted or analyzed. Therefore, further studies are needed using other criteria for classifying clinician experience is needed.

Therefore, from these limitations, the significant risk factors for implant survival and MBL identified in this study should be interpreted with caution, and con- 
trolled prospective studies are required in the future.

\section{Conclusion}

Our results demonstrate that CSR 5 s was $94.9 \%$ and that after 10 years of loading was $93.2 \%$, according to the Kaplan-Meier lifetime analysis. Smoking status, spontaneous CS exposure, type of abutment connection, and implant surface may be important factors associated with implant success. However, there was no significant correlation between the year of residence of the clinician placing the implant and implant failure.

\section{References}

1. Pjetursson BE, Zwahlen M, Lang NP. Quality of reporting of clinical studies to assess and compare performance of implant-supported restorations. J Clin Periodontol 2012;39:139-59.

2. Pjetursson BE, Tan K, Lang NP, Brägger U, Egger M, Zwahlen M. A systematic review of the survival and complication rates of fixed partial dentures (FPDs) after an observation period of at least 5 years. Clin Oral Implants Res 2004;15:667-76.

3. Vandeweghe S, De Bruyn H. The effect of smoking on early bone remodeling on surface modified Southern Implants ${ }^{\circledR}$. Clin Implant Dent Relat Res 2011;13:206-14.

4. Rosen P, Clem D, Cochran D, Froum S, McAllister B, Renvert S, Wang HL. Peri-implant mucositis and peri-implantitis: a current understanding of their diagnoses and clinical implications. J Periodontol 2013;84:436-43.

5. Costa FO, Takenaka-Martinez S, Cota LO, Ferreira SD, Silva GL, Costa JE. Peri-implant disease in subjects with and without preventive maintenance: a 5-year follow-up. J Clin Periodontol 2012;39:173-81.

6. Pjetursson BE, Helbling C, Weber HP, Matuliene G, Salvi GE, Brägger U, Schmidlin K, Zwahlen M, Lang NP. Peri-implantitis susceptibility as it relates to periodontal therapy and supportive care. Clin Oral Implants Res 2012;23:888-94.

7. Bain CA. Implant installation in the smoking patient. Periodontol 2000 2003;33:185-93.
8. Hinode D, Tanabe S, Yokoyama M, Fujisawa K, Yamauchi E, Miyamoto Y. Influence of smoking on osseointegrated implant failure: a meta-analysis. Clin Oral Implants Res 2006;17:473-8.

9. Klokkevold PR, Han TJ. How do smoking, diabetes, and periodontitis affect outcomes of implant treatment? Int J Oral Maxillofac Implants 2007;22 Suppl:173-202.

10. Strietzel FP, Reichart PA, Kale A, Kulkarni M, Wegner B, Küchler I. Smoking interferes with the prognosis of dental implant treatment: a systematic review and meta-analysis. J Clin Periodontol 2007;34:523-44.

11. Lambert PM, Morris HF, Ochi S. The influence of smoking on 3-year clinical success of osseointegrated dental implants. Ann Periodontol 2000;5:7989.

12. Kumar A, Jaffin RA, Berman C. The effect of smoking on achieving osseointegration of surfacemodified implants: a clinical report. Int J Oral Maxillofac Implants 2002;17:816-9.

13. Mellado-Valero A, Ferrer García JC, Herrera Ballester A, Labaig Rueda C. Effects of diabetes on the osseointegration of dental implants. Med Oral Patol Oral Cir Bucal 2007;12:E38-43.

14. Salvi GE, Carollo-Bittel B, Lang NP. Effects of diabetes mellitus on periodontal and peri-implant conditions: update on associations and risks. J Clin Periodontol 2008;35:398-409.

15. Enkling N, Jöhren P, Klimberg T, Mericske-Stern R, Jervøe-Storm PM, Bayer S, Gülden N, Jepsen S. Open or submerged healing of implants with platform switching: a randomized, controlled clinical trial. J Clin Periodontol 2011;38:374-84.

16. Haas R, Mensdorff-Pouilly N, Watzek G, Mailath M, Lill W, Reichsthaler J, Frey G, Thornton B. Kaplan und Meier - Vergleichsanalyse von 3000 gesetzten implantaten. In: GOI gesellschaft für orale implantologie. Jahrbuch für Orale Implantologie. Berlin; Quintessenz; 1994. p. 213-25.

17. Preiskel HW, Tsolka P. Treatment outcomes in implant therapy: the influence of surgical and prosthodontic experience. Int J Prosthodont 1995;8:273-9.

18. Zoghbi SA, de Lima LA, Saraiva L, Romito GA. Surgical experience influences 2 -stage implant os- 
seointegration. J Oral Maxillofac Surg 2011;69: 2771-6.

19. Kohavi D, Azran G, Shapira L, Casap N. Retrospective clinical review of dental implants placed in a university training program. J Oral Implantol 2004;30:23-9.

20. Melo MD, Shafie H, Obeid G. Implant survival rates for oral and maxillofacial surgery residents: a retrospective clinical review with analysis of resident level of training on implant survival. J Oral Maxillofac Surg 2006;64:1185-9.

21. Zupnik J, Kim SW, Ravens D, Karimbux N, Guze K. Factors associated with dental implant survival: a 4-year retrospective analysis. J Periodontol 2011;82:1390-5.

22. Chang M, Wennström JL, Odman P, Andersson B. Implant supported single-tooth replacements compared to contralateral natural teeth. Crown and soft tissue dimensions. Clin Oral Implants Res 1999;10:185-94.

23. Reddy MS, Mayfield-Donahoo T, Vanderven FJ, Jeffcoat MK. A comparison of the diagnostic advantages of panoramic radiography and computed tomography scanning for placement of root form dental implants. Clin Oral Implants Res 1994;5:22938.

24. De Bruyn H, Vandeweghe S, Ruyffelaert C, Cosyn J, Sennerby L. Radiographic evaluation of modern oral implants with emphasis on crestal bone level and relevance to peri-implant health. Periodontol 2000 2013;62:256-70.

25. Cardaropoli G, Lekholm U, Wennström JL. Tissue alterations at implant-supported single-tooth replacements: a 1-year prospective clinical study. Clin Oral Implants Res 2006;17:165-71.

26. Manz MC. Factors associated with radiographic vertical bone loss around implants placed in a clinical study. Ann Periodontol 2000;5:137-51.

27. Roos J, Sennerby L, Lekholm U, Jemt T, Gröndahl $\mathrm{K}$, Albrektsson T. A qualitative and quantitative method for evaluating implant success: a 5-year retrospective analysis of the Brånemark implant. Int J Oral Maxillofac Implants 1997;12:504-14.

28. Heitz-Mayfield LJ, Huynh-Ba G. History of treated periodontitis and smoking as risks for implant therapy. Int J Oral Maxillofac Implants 2009;24 Suppl:39-68.

29. Bain CA, Moy PK. The association between the failure of dental implants and cigarette smoking. Int J Oral Maxillofac Implants 1993;8:609-15.

30. Wennström JL, Palmer RM. Consensus report of session C. In: Lang NP, Karring T, Lindhe J, editors. Proceedings of the $3^{\text {rd }}$ European Workshop on Periodontology. Berlin; Quintessenz Verlags; 1999. p. 255-9.

31. Berglundh T, Persson L, Klinge B. A systematic review of the incidence of biological and technical complications in implant dentistry reported in prospective longitudinal studies of at least 5 years. J Clin Periodontol 2002;29:197-212.

32. Ekfeldt A, Christiansson U, Eriksson T, Lindén U, Lundqvist S, Rundcrantz T, Johansson LA, Nilner K, Billström C. A retrospective analysis of factors associated with multiple implant failures in maxillae. Clin Oral Implants Res 2001;12:462-7.

33. Schwartz-Arad D, Dolev E. The challenge of endosseous implants placed in the posterior partially edentulous maxilla: a clinical report. Int J Oral Maxillofac Implants 2000;15:261-4.

34. Koo KT, Lee EJ, Kim JY, Seol YJ, Han JS, Kim TI, Lee YM, Ku Y, Wikesjö UM, Rhyu IC. The effect of internal versus external abutment connection modes on crestal bone changes around dental implants: a radiographic analysis. J Periodontol 2012; 83:1104-9.

35. Peñarrocha-Diago MA, Flichy-Fernández AJ, Alonso-González R, Peñarrocha-Oltra D, BalaguerMartínez J, Peñarrocha-Diago M. Influence of implant neck design and implant-abutment connection type on peri-implant health. Radiological study. Clin Oral Implants Res 2013;24:1192-200.

36. Vázquez Álvarez R, Pérez Sayáns M, Gayoso Diz P, García García A. Factors affecting peri-implant bone loss: a post-five-year retrospective study. Clin Oral Implants Res 2015;26:1006-14.

37. Abrahamsson I, Berglundh T. Effects of different implant surfaces and designs on marginal bone level alterations: a review. Clin Oral Implants Res 2009;20:207-15. 


\section{임플란트의 생존과 변연골 소실에 영향을 미치는 인자들}

\section{송을락 ${ }^{+}$, 이재관 ${ }^{+}$, 엄흥식, 박세환, 장범석*}

강릉원주대학교 치과대학 치주과학교실

목적: 이 연구의 목적은 임플란트의 생존율과 주위 변연골 수준을 후향적으로 평가하여, 술자의 임상적 경험을 포함한 요인들이 미치는 영향을 분석하고자 하였다.

연구 재료 및 방법: 2002년 1월부터 2009년 3월까지 강릉원주대학교치과병원 치주과에서 전공의가 2단계법으로 식립한 임플란트 중 5년 이상의 기록이 있는 146명의 420개 임플란트를 대상으로, 임플란트 탈락여부, 주위 골 소실량, 성별, 연 령, 2형 당뇨, 흡연, 지대주 연결 형식, 표면 처리 방법, 직경, 식립 부위, 식립 당시 전공의 연차, 덮개 나사의 조기 노출, 보 철학적 합병증, 동반된 골 이식 술식 등의 영향을 평가하였다.

결과: 최종 보철물 장착 후 5년간 누적생존율은 $94.9 \%$ 이었다. 이원로지스틱회귀분석 결과, 흡연과 덮개 나사의 조기 노 출이 실패율을 유의하게 증가시켰다. 다중회귀분석 결과, 흡연, 임플란트 지대주 연결 형식, 및 표면 처리 방법이 임플란 트 주위 변연골 수준 변화에 유의한 영향을 주었다. 술자의 임상경험을 반영하기 위한 식립 당시의 전공의 수련 연차는 임플란트의 실패와 유의한 연관성은 보이지 않았다 $(P=0.171)$.

결론: 흡연, 덮개 나사의 조기 노출, 지대주 연결 형식 및 표면 처리 방법이 임플란트의 성공과 유의한 상관관계를 보이는 것으로 생각된다.

(구강회복응용과학지 2016;32(4):280-92)

주요어: 치과용 임플란트; 치조골 소실; 누적 생존율; 위험 인자

*교신저자: 장범석

(25457) 강원도 강릉시 죽헌길 7 강릉원주대학교 치과대학 치주과학교실

Tel: 033-640-3188 || Fax: 033-640-3113 | E-mail: dentist@gwnu.ac.kr 접수일: 2016년 9월 9일 | 수정일: 2016년 12월 5일 | 채택일: 2016년 12월 13일 + 이 저자들은 본 연구에 동일한 공여를 하였음. 